\title{
A Senior Teacher's Implementation of Technology Integration
}

\author{
Hsien-Chang Tsai ${ }^{1}$ \\ ${ }^{1}$ Department of Biology, National Changhua University of Education, Changhua, Taiwan \\ Correspondence: Hsien-Chang Tsai, Department of Biology, National Changhua University of Education, No. 1, \\ Jin-De Road, Changhua 50007, Taiwan. Tel: 886-4-723-2105. E-mail: bihft@cc.ncue.edu.tw
}

Received: January 23, 2015 Accepted: February 23, 2015 Online Published: May 28, 2015

doi:10.5539/ies.v8n6p151

URL: http://dx.doi.org/10.5539/ies.v8n6p151

\begin{abstract}
This study investigated whether a senior teacher with many years of teaching experience, despite lacking adequate technology skills or contending with other barriers, can sufficiently implement technology integration in the classroom. The research was conducted between October 2013 and January 2014 and was focused on a junior high school biology teacher with 17 years of instructional experience. A qualitative method involving semistructured interviews and classroom observation of 4 conducted lessons was used to explore the teacher's implementation of technology integration. The analytical results showed that the teacher's perspectives on technology integration ranged from "technology as a tool for teaching" to "technology as a learning activator." Moreover, external factors such as poor technology management affected the teacher's implementation of technology integration. In addition, the teacher developed a technological-pedagogical-content-knowledge base, building on current pedagogical content knowledge. The findings of this study enhance the general understanding of the development and implementation of senior teachers regarding technology integration, as well as the integration of subject content and pedagogical knowledge in teaching.
\end{abstract}

Keywords: technology integration, senior teachers, technological pedagogical content knowledge (TPACK), professional development

\section{Introduction}

Because of the increased use of technology in schools, teachers should employ technology to enhance their instructional quality and thus enhance the learning experience of students (Cuban, 2001; Desimone, 2009; Maskit, 2011). Studies have demonstrated the importance of using technology in teaching to improve student learning (Merrill, 1996; Kearsley \& Shnedierman, 1998; Backhouse, 2003). However, senior teachers with comprehensive instructional experience and confidence in their teaching strategies seldom apply technology in their classes (Russel, Finger, \& Russel, 2000; Williams, Coles, Richardson, Wilson, \& Tuson, 2000). Pelgrum (2001) indicated that rather than being unwilling to use technology, senior teachers are insufficiently able to do so. Therefore, research is warranted on whether senior teachers who have many years of teaching experience, despite lacking adequate technology skills or contending with other barriers, can sufficiently implement technology integration in the classroom.

Pamuk (2012) demonstrated that technology helps teachers develop innovative instructional methods. However, teachers' lacking computer literacy in most countries constitutes a major impediment in this regard. Studies have indicated that although many teachers often use technology in their daily lives, they do not apply it in class (Cuban, 1993; Ertmer, 2005; Park \& Son, 2009; Wang, 2007). Furthermore, studies have claimed that even if schools provided adequate hardware and software, many teachers would still follow the traditional way of teaching (Mumtaz, 2000).

The major reason for a lack of technology use is that teachers are unable to integrate technology with classroom instructional strategies (Niess, 2011; Wetzel \& Marshall, 2011). Thus, if teachers possess only technology skills without a strategy for implementation, they might integrate technology insufficiently in their classrooms. Dutt-Doner, Allen, and Corcoran (2005) described how integrating technology in teaching should not involve focusing on the improvement of technology skills; rather, it should support teachers in adequately combining teaching strategies and required subject-content knowledge. Dawson (2012) demonstrated that in addition to technology skills, the ability to integrate subject content knowledge and instructional strategies is vital for facilitating adequate technology application in the classroom. Hence, a teacher should be encouraged to integrate 
teaching strategies and subject content knowledge with technology skills in teaching.

Sufficient technology integration in instruction should not only include pedagogical content knowledge (PCK), which was proposed by Shulman (1986), but also be expanded to include technological pedagogical content knowledge (TPACK), as proposed by Mishra and Koehler (2006). Therefore, TPACK - connecting the three elements of PCK, technological content knowledge (TCK), and technological pedagogical knowledge (TPK) - is associated with improving student learning. The concepts underlying TPACK and its components comprise the primary criteria for technology integration in teaching, thus indicating the direction of teachers' professional development regarding technology integration.

Numerous studies have investigated the perspectives on technology integration of general teachers such as preservice teachers and primary school teachers (Carr-Chellman \& Dyer, 2000; Glover \& Miller, 2001; Wong, 2013; Zepp, 2005), whereas few studies have focused on the instructional practices of senior teachers. According to Chen and Jang (2014), senior teachers are interested in learning about technology and how to improve their use of technology in the classroom; they also care about how technology affects their instruction. Considering the effects of digital technology on current schooling, the implementation of technology integration by senior teachers warrants investigation. Thus, this study explored the implementation of technology integration into instruction by a senior teacher.

\section{Literature Review}

\subsection{Ability of Senior Teachers to Integrate Technology into Instruction}

According to D. Govender and I. Govender (2014), most teachers with access to technology and competency in using computers do not apply technology in their instruction. Generally, teachers are divided into two categories regarding their perspectives on technology integration in the classroom. The first category comprises teachers who exhibit a positive attitude toward technology integration and believe that technology integration not only makes teaching more efficient and effective but also enhances the motivation of students and the demonstration of interdisciplinary knowledge (Beeland, 2002; Iding, Crosby, \& Thomas, 2002; Reiser, 2002). By contrast, the second category consists of teachers who believe that technology blurs the learning focus of students and thus inadvertently interferes with learning (Lavie, 2005). Despite most teachers recognizing the benefits of technology integration in the classroom (Voogt, Tilya, \& Akker, 2009), a lack of successful experiences may influence their motivations to apply technology in teaching (Slaouti \& Barton, 2007; Balanskat, Blamire, \& Kefala, 2006). Thus, creating successful experiences of technology integration might entice teachers to apply technology in the classroom.

Furthermore, successful experiences in technology integration involve integrating pedagogical knowledge (PK), subject content, and technological skills. Studies have demonstrated that teachers who did not integrate their instruction with technology, strategies, and content knowledge (CK) implemented technology use in their teaching insufficiently (Russel et al., 2000; Williams et al., 2000). Doukakis et al. (2010) examined 1,032 senior high school teachers' technology use in instruction and suggested that teachers exhibited poor performance. Kadijevich (2012) suggested that teachers lacked an adequate TPACK base for applying technology in the classroom. Thus, teachers with unsuccessful experiences in technology integration might lack an adequate TPACK base.

When teachers lack the ability to integrate technology into their instruction, they might not consider technology integration as part of an effective teaching method and even develop a negative attitude toward technology integration. Hung and Hsu (2007) contended that old-aged and senior teachers with substantial teaching experience generally exhibited a less positive attitude toward computers, especially when compared with the findings of Comber, Colley, Hargreaves, and Dorn (1997), indicating that young-aged or novice teachers exhibited a more positive attitude toward technology; their frequency in using computers were also higher than that of senior teachers.

The ability to integrate technology into instruction is vital for the professional development of teachers. Regarding senior teachers, studies have demonstrated that the pedagogical knowledge of in-service teachers encourages their integration of ICT (Harris, Grandgenett, \& Hofer, 2010; Liu, 2013). Moreover, other studies have proposed that in-service teachers were mainly concerned with subject content when they integrated technology into their instruction (Graham, Borup, \& Smith, 2012; Koh \& Divaharan, 2011; Koh \& Chai, 2014). Most senior teachers with PK and CK that exceeded their TK can consider various instructional strategies and subject content and seek technology that matches their preferences regarding technological integration. Thus, senior teachers can be expected to apply a PK base, combined PK and subject content, and technology during a professional development program, and thus lay the groundwork for the application of a TPACK framework. 


\subsection{Factors Influencing the Technology Integration of Teachers}

Another possible reason for insufficient technology integration of teachers is the existence of barriers. Leggett and Persichitte (1998) proposed that teachers who integrated technology into instruction typically encountered five barriers: a) time (lack of time to prepare relevant curricula and teaching materials as well as lack of time to promote technology literacy); b) professionalism (lack of sufficient technology skills as well as lack of opportunities and access to relevant training); c) access (lack of computer hard- or software and network equipment); d) resources (lack of experts to assist teachers in applying technology as well as insufficient purchasing, upgrading, or maintenance of equipment; and e) support (lack of leadership and support from school administrations). Lan (2001) investigated secondary school teachers from a school well-known for integrating technology into instruction and identified factors affecting teachers in the use of technology, including external stimuli (peer influence and the supervisor's teaching style), the environment (software, hardware, and school atmosphere), and the intrinsic belief (the faith in enabling students to learn concepts by using technology, regardless of the teachers' predisposition). Additionally, Backhouse (2003) proposed that the problems of technology integration were mainly that many schools focused too much on the construction of technological equipment and networks but not on instructing teachers how to apply the technology to enhance the effectiveness of their instruction. Adams (2005) also asserted that the biggest factor affecting technology use is the ability of teachers to integrate technology skills and instructional strategies. Furthermore, Wanjira (2005) suggested that sufficient technology use in teaching depends on relevant expertise and skills in addition to the management of technology resources.

Based on the aforementioned studies, two types of factor that influence teachers' implementation of technology integration can be identified: personal factors and external factors. Personal factors include the ability to integrate technology in teaching, perception and attitude toward technology integration, and level of experience applying technology in instruction. External factors involve the availability of technological equipment, administrative support, peer influence, and restrictions of time and budget.

Regarding senior teachers, the many years of teaching and their associated comprehensive experience easily lead to the assumption that they ought to understand how to integrate technology in teaching and engender successful experiences in technology integration. However, substantial barriers exist and whether these also limit senior teachers in implementing technology integration is not clear. To address this question, this study involved interviewing and observing a senior teacher who was encouraged to implement technology integration, and examining the teacher's perspectives, influencing factors, and professional development regarding the application of technology in instruction. The study also addressed the following specific research questions:

1) What are the perspectives of the senior teacher on technology integration before implementation? Is there any change in technology integration after implementation?

2) Which factors affect the senior teacher's implementation of technology integration? Is there any barrier to technology integration?

3) How does the senior teacher develop knowledge of technology integration in terms of a TPACK framework?

\section{Methodology}

\subsection{Research Design}

A teacher's implementation of technology integration in the classroom is complicated and contextual. Qualitative methods, including a semistructured interview technique and classroom observation covering four lessons were employed to explore the context of the instructional practice. Moreover, to a ensure credible qualitative research, a self-evaluation scale in relation to the TPACK framework was used to collect the teacher's self-perception on technology integration. In addition, the study involved video-recording classes given by the teacher, and combining these with the researcher's analytical log, recording the behaviors of the teacher and students during the classroom observation. The researcher clarified the observed data and triangulated the data obtained from classroom observation, interviews, and the self-evaluation scale.

\subsection{Participant}

According to Unruh and Turner (1970), a teacher with more than 15 years of teaching experience can be considered a senior teacher. The study invited a junior high school biology teacher, Ms. Chen, with 17 years of teaching experience, to participate in this study between October 2013 and January 2014. She graduated from the biology-related department of a Taiwanese university. Ms. Chen occasionally applied technology in instruction. In addition, she was familiar with operating technology for teaching and occasionally participated in technological courses to acquire advanced skills. Ms. Chen often discussed instructional methods and 
teaching-related activities with her colleagues (student teachers and peer teachers). Her belief regarding teaching was based on student-centered instruction. She held the opinion that a teacher should be a facilitator of learning rather than an agent of knowledge delivery.

Ms. Chen works at a large junior high school, located in Changhua, Taiwan that has a total of 67 classes. The average number of students in a class ranges from 30 to 35. Ms. Chen teaches two classes of Grade 7 and two classes of Grade 9. The instructional activities of the four classes constituted the data sources for the study. Although the school has a biology laboratory shared by all biology teachers, it requires registering prior to use. Thus, if there is no explicit need to use the designated biology classroom, Ms. Chen teaches her biology class in a general classroom. While teaching, Ms. Chen often asks students to discuss topics in groups. Furthermore, if her students have any questions about the subject matter, she encourages them to raise their hands to ask a question anytime. Her classroom is equipped with a projector and screen but no computer; thus, Ms. Chen must bring her own laptop or borrow one from the school administration to present PowerPoint slides or videos in the classroom.

\subsection{Instruments}

\subsubsection{Self-Evaluation Scale of Technology and Pedagogical Knowledge}

The self-evaluation scale for determining senior teachers' perceptions on technology integration was modified by Schmidt et al. (2009), and Angeli and Valanides (2009). The scale consists of seven dimensions: technology knowledge (TK), CK, PK, PCK, TCK, TPK, and TPACK, comprising 33 items and was validated by a professor with education expertise, an assistant professor with biology education expertise, and three junior high school senior teachers.

Ms. Chen was required to complete the scale before implementing instructional activities. After completing the instructional activities comprising four lessons, she filled in the scale again and was interviewed. By comparing two scales with the data obtained from the classroom observations and interviews, the study identified the changes in perspectives on technology integration.

\subsubsection{Semistructured Interviews}

Five semistructured interviews were conducted; the first one before the start of any study-related instructional activities and subsequently after each of the four observed lessons. To reflect the research objective, the questions of the interviews comprised two approaches, perspectives of, and factors influencing the application of technology in teaching. In addition, by comparing the interview data with self-evaluation scale, the teacher's changes in, and the professional developments regarding technology integration were identified.

The interview questions about the perspectives of technology use were based on Cope and Ward (2002), who conceptualized the perception of technology use based on three aspects: "what," "how," and "why." "What" refers to the definition of technology use, "how" refers to the manner of integrating technology into teaching, and "why" refers to the reasons for using technology.

The questions related to the factors affecting the teacher's strategies for applying technology were based on Koh, Chai, and Tay (2014), and comprised four categories: physical/technological, cultural/institutional, interpersonal, and intrapersonal.

\subsubsection{Classroom Observation}

The classroom observations allowed Ms. Chen to share her ideas on activities regarding technological integration. Her teaching demonstration enabled triangulating the data obtained from her descriptions in interviews. All instructional activities were video-recorded. To ensure close attention was paid to conducting classroom observations, the researcher developed specific categories of observation based on the elements of the TPACK framework, including PCK, TCK, and TPK, and further recorded the behaviors of teachers during instruction.

\subsection{Data Analysis}

Constant-comparison analysis was used to analyze the data obtained from the self-evaluation scale, interviews, and video-recorded classroom observations. The process of analysis involved constructing headings and codes in relation to the TPACK framework, as well as Ms. Chen's perspectives on technology integration.

Upon identifying certain patterns in the data, the researcher reviewed the analytical results again to identify any salient tendencies. The comparison of the interview data and video-recorded classroom observations revealed specific events of interest and in turn revealed patterns in the data regarding technology integration activities, which were considered in the study results as related to teachers' perspectives and barriers on technology integration. Furthermore, by comparing the results of the self-evaluation scale with the analytical results, this 
study could identify the teacher's change in perspectives on technology integration.

\section{Results}

The study results adequately reflected the research questions.

\subsection{Ms. Chen's Perspectives on Technology Integration}

Initially, Ms. Chen presented lectures using PowerPoint slides. The initial perception of Ms. Chen regarding technology integration was that technology constituted a tool for presenting instructional material.

Technology use in teaching should connect with the lesson content. As long as using technology or multimedia in class, it all belongs to "technology integration into instruction." Besides, technology is just like an assistant of teaching, such as providing PowerPoint slides, it can show the teaching material ... (Interview, October 11, 2013).

Ms. Chen considered many concepts in the biology curriculum as too abstract for junior high school students and therefore regarded a technological aid as necessary to provide concrete representations.

For a recent example of teaching genetic unit, the concept of chromosome is very abstract, so students must rely on imagination. At this time, I make some simple animated pictures through slides and use some videos which can present clear imagination. I discover that the animated pictures not only caught students' attentions but also help them to change students' misconceptions . . . (Interview, November 22, 2013).

According to Ms. Chen, applying technology in teaching is necessary for elucidating abstract concepts in instructional materials and facilitating instruction, as well as ensuring the understanding of students. This was Ms. Chen's instructional decision of technology integration. The consideration of whether to implement technology integration thus seemingly depends on whether the technology facilitates a better understanding of abstract concepts by the students.

After the instructional activities of three lessons, the viewpoint of Ms. Chen began to change. By viewing the video recordings, it became evident that the PowerPoint slides tended to be simple and contained few pictures. According to relevant studies (Bauer, Derntl, Motschnig-Pitrik, \& Tausch, 2006; Motschnig-Pitrik \& Derntl, 2005; Derntl \& Calvo, 2011), it is assumed that eliminating redundant information reduces the cognitive load of junior high school students. Moreover, creating animated sequences from static pictures reveals contextual concepts. The perspective was validated by data triangulation. Ms. Chen expressed the following:

I think the best use of technology in teaching is that the complex concept is simplified, so it can help students to understand what I said. For example, I previously taught that plants' stems have phototropism and negative geotropism. The qualities of stems are the opposite with the qualities of the roots totally, thus students get confused easily. At this time, I think that it's more useful that get them a small animation directly than tell them to remember (Interview, December 15, 2013).

Ms. Chen expressed the belief that applying technology simplifies complex concepts and enables students to comprehend abstract concepts more easily. Notably, Ms. Chen made the animation by herself to help students quickly understand a given concept. Thus, she became more confident in technology integration.

I found that my students became more active in class and their reaction to teaching also became more quickly than ever when I use technology in teaching. In addition, most of them paid attention to my teaching activities. So, I became more confident in my teaching. I think that I would gradually like to use technology in teaching ... Technology use was beneficial for my class (Interview, December 15, 2013).

This description by Ms. Chen was also confirmed by the classroom observation: "I discovered that the students became more vivid and interesting to response the teacher's question” (Observation, December 8, 2013).

However, although Ms. Chen felt that the students exhibited heightened interested in technology use, she admitted that implementing all of the instructional activities required excessive time: "I always spent too much time responding students' questions, especially when my material is interesting to the students. Sometimes, I occupied recesses time of students." (Interview, December 15, 2013).

In conclusion, Ms. Chen recognized that technology use motivated the students to learn. Therefore, the perspectives of teachers regarding technology integration seem to range from "technology as a tool for teaching" to "technology as a learning activator." Teachers' changes in perception regarding technology application are ostensibly caused by the change in motivation and activity levels of the students. Ms. Chen also recognized the 
benefits of technology integration based on her instructional activities.

\subsection{Factors Influencing a Senior Teacher's Implementation of Technology Integration}

According to the analytical results, four factors affect teachers' use of technology in class: a) the teacher's belief in pedagogy; b) learning effectiveness; c) familiarity with technology; and d) Appropriateness of the integration regarding subject contents.

Through the classroom observation, it was established that the students were often asked to think (Observation, November 15, 2013). Ms. Chen expressed in the interview before the instructional activities that all students must construct their own view and be able to make reasonable and defendable claims. After conducting the instructional activities, she expressed the following:

My idea about teaching is to enable students to understand the concepts, not to remember any factual knowledge. Before participating in this study, I often employed the way of argument to let my students construct their own thoughts. When I taught the chapter of biotechnology, I would divide students into two groups to discuss the issue of human cloning ... In the study, the animated pictures can provide my students to predict the answer on next screen. The activities of discussion with slides presentation can train their eloquence and equip them with their ability to think critically (Interview, October 25, 2013).

Moreover, Ms. Chen's consideration regarding technology integration was how to enhance the effectiveness of learning by applying technology, as expressed in the following.

I think the learning effectiveness is my concerns during technology integration. I have seen many studies that suggested that technology itself wouldn't be able to enhance students' learning . . . When meeting this chapter which might easily produce misconcepts, I would try to clearly describe with the animate pictures (Interview, November 22, 2013).

Ms. Chen's technology skills affected her application of technology. During classroom observation, Ms. Chen used PowerPoint slides and designed animated pictures using PowerPoint (Observation, October 18, 2013). Available technology skills enabled Ms. Chen to integrate technology into teaching. This study confirmed this observation by analyzing the interview data.

Ms. Chen considered the appropriateness of the integration regarding subject contents before integrating technology in teaching: "If I am familiar with this technology, I will use it in teaching. In fact, a class time is only 45 minutes. If the technology is not good to use, I think general teachers would not use it" (Interview, December 15, 2013). As established by the classroom observation, Ms. Chen did not apply technology in all instructional activities. Sometimes she employed traditional approaches because of the inappropriateness of subject contents. The analytical results of the interview data corroborated this observation.

I think subject content is also a big factor influencing me to use technology. Some lessons, such as "cycle and genetics," I use digital animated pictures in my teaching activities. After all, those contents are really abstract. If only presenting the contents in a single static way like textbooks, students must be confused. Animated pictures and videos are necessary (Interview, January 10, 2014).

As for the barriers that senior teachers face regarding technology integration, poor technology management is a key factor. Even though Ms. Chen understood how to integrate technology into instruction, insufficient technology support reduced her motivation.

My school has bought interactive whiteboards (IWB) that motivated me to use it in teaching, but IWB is difficult to use. For example, when I need to use it in next class, I must go to digital classroom to adjust the position of IWB and set up the screen light-spot before class begins. Sometimes the IWB position is not always accurate. Students frequently do not know where I am pointing . . . (Interview, January 10, 2014).

The barriers in technology integration are not caused by the inadequate ability of a teacher to integrate technology, subject content, and PK, but by the nature of external support. Although Ms. Chen is a senior teacher, she is willing to learn how to use innovative technology. However, poor technology management caused her to use only controllable equipment such as the classroom projector and PowerPoint slides. Thus, external factors such as technology management and administrative support affect senior teachers' implementation of technology integration.

\subsection{Development of Ms. Chen Regarding Technology Integration Knowledge}

By analyzing the implementation in technology integration, the study discovered that Ms. Chen had the ability to 
integrate technology, pedagogy, and $\mathrm{CK}$ as indicated by the following example of a classroom observation:

Ms. Chen teaches the lesson content in relation to the nutrients in food and energy. She asks students to discuss by groups and then to write a worksheet ... Afterward, Chen asks students to present the worksheet through a projector in front of classroom (Observation, December 1, 2013).

Ms. Chen stated that this method enables all students to see the presented worksheets, rather than merely hearing them explained, as in traditional teaching methods. During presentations, she immediately pointed out the mistakes of the students and asked other students to correct them.

After participating in the study, Ms. Chen recognized that her instructional strategies had changed because of applying technology. She recalled specific instructional activities as follows:

In the beginning, I only anticipated that students would be interested in technology integration and might actively respond my lesson question. However, when I found that students really like this teaching activities with technology, I begin to consider alternative strategies like student presentation that was seldom used in teaching (Interview, January 10, 2014).

Comparing the above analytical results with the self-evaluation scale completed after the instructional activities, this study determined that Ms. Chen had sufficiently developed TPACK in teaching. Initially, she was accustomed to applying PowerPoint in presenting abstract biology CK. This developed only her TCK base and entailed insufficient implementation of TPACK. When Ms. Chen employed the strategy for integrating student presentations and experienced the learning effectiveness of technology integration, the TPACK framework was developed by integrating the TCK with various types of PK. Thus, she experienced a process of professional development in technology integration. Based on the initial consideration of abstract content, as well as the final application of PK, the implementation of a TPACK framework emerged.

\section{Conclusion and Discussion}

This study investigated the implementation of technology integration into instruction of a senior teacher. This paper examined the teacher's perspectives, influencing factors, and professional development regarding technology use in instruction. According to the analytical results, the senior teacher's perspectives on technology integration ranged from "technology as a tool for teaching" to "technology as a learning activator." Moreover, external factors like poor technology management affected the senior teachers' implementation of technology integration. In addition, the senior teacher developed a TPACK base, building on her current PCK.

The changes in perspective of the senior teacher regarding technology use in instruction are determined by her students' learning behaviors and active responses. The students were highly interested in the classes in which technology was employed, causing the teacher to consider how to innovatively integrate technological functions with abstract CK. When the students exhibited a high motivation to learn, the teacher became confident in technology integration. Furthermore, the senior teacher recognized the benefits of applying technology in instruction.

During the instructional activities of four lessons, the senior teacher regarded the learning effectiveness as a key factor in integrating technology into instruction. The results of this study are consistent with a previous study (Lan, 2001), indicating that experienced teachers focused on their instruction and whether they achieved their teaching objectives. Moreover, based on the study results it is possible to identify the factors determining a teacher's familiarity with technology and the appropriateness of integration with the subject contents, affecting technology integration, as reported in previous studies (Leggett \& Persichitte, 1998; Backhouse, 2003; Adams, 2005). It is reasonable that a senior teacher with insufficient technology skills considers subject content knowledge and learning effectiveness as the key factors in whether to implement technology integration.

However, poor technology management is likely to reduce the willingness of senior teachers to implement innovative teaching technology. When technology amounts to an inconvenient teaching tool, teachers do not use it in the classroom. Pelgrum (2001) indicated that the reason why senior teachers seldom apply technology in instruction is the lack of sufficient ability to use it; however, regarding the current generation of junior school teachers, in-service training has equipped teachers with adequate technology skills. Assuming that advanced technology skills do not constitute a crucial factor in technology integration, it is reasonable to suspect external factors, such as the management of equipment, to be a key factor influencing the technology integration of senior teachers.

The senior teacher in this study exhibited an optimistic attitude toward technology integration. As suggested by Hung and Hsu (2007), the senior teacher was willing to acquire innovative technology skills under the condition of being provided with sufficient in-service training. The senior teacher was also aware of how technology 
integration benefitted the students' learning. However, regardless of which technology was applied, the senior teacher primarily focused on subject content and pedagogical methods when integrating technology in the classroom.

Based on these considerations, the development of a TPACK framework emerged. Unlike young teachers who may have abundant technology skills, the senior teacher developed a TPACK framework on the foundation of her current PCK, as evidenced by previous studies (Graham et al., 2012; Koh \& Divaharan, 2011; Koh \& Chai, 2014; Liu, 2013), indicating that experienced teachers typically focus on subject content and instructional strategies when integrating technology.

In this study, a senior teacher developed professionally in technology integration. This process of professional development provides an example for current senior teachers, especially for senior teachers. In this study, the development and implementation of technology integration were based on the integration with sufficient subject content and PK, adequately adapted to the characteristics of senior teachers. The study results could encourage senior teachers to implement sufficient technology integration.

The findings of this study enhance understanding of the development and implementation of senior teachers in integrating technology in a school setting. The findings also contribute to the literature by identifying that the development and implementation of technology integration for senior teachers depends on sufficient subject content and pedagogical knowledge.

\section{References}

Adams, S. T. (2005). A strategy for technology training as part of a master's program conducted at a school site. Journal of Technology and Teacher Education, 13(Autumn), 493-515.

Angeli, C., \& Valanides, N. (2009). Epistemological and methodological issues for the Conceptualization, development, and assessment of ICT-TPCK: Advances in technological pedagogical content knowledge (TPCK). Computers \& Education, 52(1), 154-168. http://dx.doi.org/10.1016/j.compedu.2008.07.006

Backhouse, B. (2003). Information and communication technology integration: Beyond the early adopters. TechTrends, 47(3), 5-8. http://dx.doi.org/10.1007/BF02763468

Balanskat, A., Blamire, R., \& Kefala, S. (2006). The ICT Impact Report: A review of studies of ICT impact on schools in Europe. European Schoolnet.

Bauer, C., Derntl, M., Motschnig-Pitrik, R., \& Tausch, R. (2006). Promotive activities in face-to-face and technology-enhanced learning environments. The Person-Centered Journal, 13(1), 12-37.

Beeland, W. D. Jr. (2002). Student engagement, visual learning and technology: Can interactive whiteboards help? Paper presented at the Annual Conference of the Association of Information Technology for Teaching Education, Trinity College, Dublin.

Carr-Chellman, A. A., \& Dyer, D. (2000). The pain and ecstasy: Pre-service teacher perceptions on changing teacher roles and technology. Educational Technology \& Society, 3(2), 96-105.

Chen, Y.-H., \& Jang, S.-J. (2014). Interrelationship between stages of concern and technological, pedagogical, and content knowledge: A study on Taiwanese senior high school in-service teachers. Computers in Human Behavior, 32, 79-91. http://dx.doi.org/10.1016/j.chb.2013.11.011

Comber, C., Colley, A., Hargreaves, D. J., \& Dorn, L. (1997). The effects of age, gender and computer experience upon computer attitude. Educational Research, 39(2), 123-133. http://dx.doi.org/10.1080/0013188970390201

Cope, C., \& Ward, P. (2002). Integrating learning technology into classrooms: The importance of teachers' perceptions. Education Technology \& Society, 5(1), 67-74.

Cuban, L. (1993). How teachers taught: Constancy and change in American classrooms, 1890-1990 (2nd ed.). New York, NY: Teachers College Press.

Cuban, L. (2001). Oversold and underused. Cambridge, MA: Harvard University Press.

Dawson, K. (2012). Using action research projects to examine teacher technology integration practices. Journal of Digital Learning in Teacher Education, 28(3), 117-124. http://dx.doi.org/10.1080/21532974.2012.10784689

Derntl, M., \& Calvo, R. A. (2011). E-learning frameworks: Facilitating the implementation of educational design patterns. International Journal of Technology Enhanced Learning, 3(3), 284-296. http://dx.doi.org/10.1504/IJTEL.2011.040225 
Desimone, L. M. (2009). Improving impact studies of teachers' professional development: Toward better conceptualizations and measures. Educational Researcher, 38(3), 181-199. http://dx.doi.org/10.3102/0013189X08331140

Doukakis, S., Psaltidou, A., Stavraki, A., Adamopulos, N., Tsiotakis, P., \& Stergou, S. (2010). Measuring the technological pedagogical content knowledge (TPACK) of in-service teachers of computer science who teach algorithms and programming in upper secondary education. In K. Fernstrom (Ed.), Readings in technology and education: Proceedings of ICICTE 2010 (pp. 442-452). Corfu, Greece.

Dutt-Doner, K., Allen, S. M., \& Corcoran, D. (2005). Transforming student learning by preparing the next generation of teachers for Type II technology integration. Computers in the Schools, 22(3-4), 63-75. http://dx.doi.org/10.1300/J025v22n03_06

Ertmer, P. A. (2005). Teacher pedagogical beliefs: The final frontier in our quest for technology integration? Educational Technology Research and Development, 53(4), 25-39. http://dx.doi.org/10.1007/BF02504683

Glover, D., \& Miller, D. (2001). Running with technology: The pedagogic impact of the large-scale introduction of interactive whiteboards in one secondary school. Journal of Information Technology for Teacher Education, 10(3), 257-278. http://dx.doi.org/10.1080/14759390100200115

Govender, D. W., \& Govender, I. (2014). Technology adoption: A different perspective in a developing country. Procedia-Social and Behavioral Sciences, 116, 2198-2204. http://dx.doi.org/10.1016/j.sbspro.2014.01.543

Graham, C. R., Borup, J., \& Smith, N. (2012). Using TPACK as a framework to understand teacher candidates' technology integration decisions. Journal of Computer Assisted Learning, 28(6), 530-546.

Harris, J., Grandgenett, N., \& Hofer, M. (2010). Testing a TPACK-based technology integration assessment rubric. In D. Gibson, \& B. Dodge (Eds.), Proceedings of Society for Information Technology \& Teacher Education International Conference 2010 (pp. 3833-3840). Chesapeake, VA: AACE.

Hung, Y.-W., \& Hsu, Y.-S. (2007). Examining teachers' CBT use in the classroom: A study in secondary schools in Taiwan. Educational Technology \& Society, 10(3), 233-246.

Iding, M., Crosby, M. E., \& Thomas, S. (2002). Teacher and technology: Beliefs and practices. International Journal of Instruction Media, 29(2), 153-170.

Kadijevich, D. M. (2012). TPCK framework: assessing teachers' knowledge and designing courses for their professional development. British Journal of Educational Technology, 43(1), E28-E30. http://dx.doi.org/10.1111/j.1467-8535.2011.01246.x

Kearsley, G., \& Shnedierman, B. (1998). Engagement theory: A framework for technology-based teaching and learning. Educational Technology, 38(5), 20-23.

Koh, J. H. L., \& Chai, C. S. (2014). Teacher clusters and their perceptions of technological pedagogical content knowledge (TPACK) development through ICT lesson design. Computers \& Education, 70, 222-232. http://dx.doi.org/10.1016/j.compedu.2013.08.017

Koh, J. H. L., \& Divaharan, S. (2011). Developing pre-service teachers' technology integration expertise through the TPACK-Developing Instructional Model. Journal of Educational Computing Research, 44(1), 35-58. http://dx.doi.org/10.2190/EC.44.1.c

Koh, J. H. L., Chai, C. S., \& Tay, L. Y. (2014). TPACK-in-Action: Unpacking the contextual influences of teachers' construction of technological pedagogical content knowledge (TPACK). Computers \& Education, 78, 20-29. http://dx.doi.org/10.1016/j.compedu.2014.04.022

Lan, J. (2001). Web-based instruction for education faculty: A needs Assessment. Journal of Research on Computing in Education, 33(4), 385-399.

Lavie, N. (2005). Distracted and confused: Selective attention under load. Trends in Cognitive Sciences, 9(2), 75-82. http://dx.doi.org/10.1016/j.tics.2004.12.004

Leggett, W. P., \& Persichitte, K. A. (1998). Blood, sweat, and TEARS: 50 years of technology implementation obstacles. TechTrends, 43(3), 33-36. http://dx.doi.org/10.1007/BF02824053

Liu, S.-H. (2013). Exploring the instructional strategies of elementary school teachers when developing technological, pedagogical, and content knowledge via a collaborative professional development program. International Education Studies, 6(11), 58-68. http://dx.doi.org/10.5539/ies.v6n11p58

Maskit, D. (2011). Teachers' attitudes toward pedagogical changes during various stages of professional 
development. Teaching and Teacher Education, 27(5), 851-860. http://dx.doi.org/10.1016/j.tate.2011.01.009

Merrill, M. D. (1996). Reclaiming instructional design. Educational Technology, 36(5), 5-7.

Mishra, P., \& Koehler, M. J. (2006). Technological pedagogical content knowledge: A framework for teacher knowledge. Teaches College Record, 108(6), 1017-1054. http://dx.doi.org/10.1111/j.1467-9620.2006.00684.x

Motschnig-Pitrik, R., \& Derntl, M. (2005). Can the Web Improve the effectiveness of person-centered learning? Case Study on Teaching and Living Web-Engineering. IADIS International Journal on WWW/Internet, 2(1), 49-62.

Mumtaz, S. (2000). Factors affecting teachers' use of information and communications technology: A review of the literature. Technology, Pedagogy and Education, 9(3), 319-342. http://dx.doi.org/10.1080/14759390000200096

Niess, M. L. (2011). Investigating TPACK: knowledge growth in teaching with technology. Journal of Educational Computing Research, 44(3), 299-317. http://dx.doi.org/10.2190/EC.44.3.c

Pamuk, S. (2012). Understanding preservice teachers' technology use through TPACK framework. Journal of Computer Assisted Learning, 28(5), 425-439. http://dx.doi.org/10.1111/j.1365-2729.2011.00447.x

Park, C. N., \& Son, J.-B. (2009). Implementing computer-assisted language learning in the EFL classroom: Teachers' perceptions and perspectives. International Journal of Pedagogies and Learning, 5(2), 80-101. http://dx.doi.org/10.5172/ijpl.5.2.80

Pelgrum, W. J. (2001). Obstacles to the integration of ICT in education: Results from a worldwide educational assessment. Computers \& Education, 37(2), 163-178. http://dx.doi.org/10.1016/S0360-1315(01)00045-8

Reiser, L. J. (2002). Professional development and other factors that contribute to the ability to integrate technology into curriculum. Journal of Educational Technology Systems, 30(4), 437-460. http://dx.doi.org/10.2190/JB9U-GJBD-LRUR-0VWU

Russel, G., Finger, G., \& Russel, N. (2000). Information technology skills of Australian teachers: Implications for teacher education. Journal of Information Technology for Teacher Education, 9(2), 149-166. http://dx.doi.org/10.1080/14759390000200087

Schmidt, D. A., Bara, E., Thompson, A. D., Mishra, P., Koehler, M. J., \& Shin, T. S. (2009). Technological pedagogical content knowledge (TPACK): The development and validation of an assessment instrument for preservice teachers. Journal of Research on Technology in Education, 42(2), 123-149. http://dx.doi.org/10.1080/15391523.2009.10782544

Shulman, L. S. (1986). Those who understand: Knowledge growth in teaching. Educational Researcher, 15(2), 4-14. http://dx.doi.org/10.3102/0013189X015002004

Slaouti, D., \& Barton, A. (2007). Opportunities for practice and development: Newly qualified teachers and the use of information and communications technologies in teaching foreign languages in English secondary school contexts. Journal of In-service Education, 33(4), 405-424. http://dx.doi.org/10.1080/13674580701687807

Unruh, A., \& Turner, H. E. (1970). Supervision for change and innovation. Boston: Houghton Mifflin.

Voogt, J., Tilya, F., \& van den Akker, J. (2009). Science teacher learning of MBL-supported student-centered science education in the context of secondary education in Tanzania. Journal of Science Education and Technology, 18(5), 429-438. http://dx.doi.org/10.1007/s10956-009-9160-8

Wang, J.-T. (2007). Technology integration in university teacher education programs in Taiwan (Unpublished doctoral dissertation). University of Walden, Minnesota, United States. Retrieved from http://search.proquest.com/docview/304764408?accountid=10046

Wanjira, K. (2005). Technology integration techniques in preservice and alternative teacher education preparation. In P. Kommers, \& G. Richards (Eds.), Preceedings of ED-MEDIA 2005 (pp. 3193-3198). Norfork, VA: AACE.

Wetzel, K., \& Marshall, S. (2011). TPACK goes to sixth grade: Lessons from a middle school teacher in a high-technology-access classroom. Journal of Digital Learning in Teacher Education, 28(2), 73-81. http://dx.doi.org/10.1080/21532974.2011.10784683

Williams, D., Coles, L., Richardson, A., Wilson, K., \& Tuson, J. (2000). Integrating information and communications technology in professional practice: An analysis of teachers' needs based on a survey of primary and secondary teachers in Scottish schools. Journal of Information Technology for Teacher 
Education, 9(2), 167-182. http://dx.doi.org/10.1080/14759390000200089

Wong, K.-T. (2013). Affordances of interactive whiteboards and associated pedagogical practices: Perspectives of teachers of science with children aged five to six years. Turkish Online Journal of Educational Technology, 12(1), 1-8.

Zepp, R. A. (2005). Teachers' perceptions on the roles on educational technology. Educational Technology \& Society, 8(2), 102-106.

\section{Copyrights}

Copyright for this article is retained by the author(s), with first publication rights granted to the journal.

This is an open-access article distributed under the terms and conditions of the Creative Commons Attribution license (http://creativecommons.org/licenses/by/3.0/). 